Socialist Studies / Études socialistes 7(1/2) Spring/Fall 2011: 216-237

Copyright (C) 2011 The Author(s)

SPECIAL ISSUE ON ORGANIZING FOR AUSTERITY: THE NEOLIBERAL STATE, REGULATING LABOUR AND WORKING CLASS RESISTANCE

\title{
Reflections on Resistance to Neoliberalism Looking Back on Solidarity in 1983 British Columbia
}

\section{TED RICHMOND and JOHN SHIELDS}

Chang School, Ryerson University. Toronto, Ontario, Canada.

Politics and Public Administration. Ryerson University, Toronto, Ontario, Canada.

\begin{abstract}
This article critically examines the 1983 British Columbia (BC) Solidarity experience, a period that marked the first comprehensive neoliberal policy revolution in Canada. It also marked the launch of an extensive movement of extra-parliamentary resistance to neoliberal attempts to undo social and economic gains achieved during the period of Keynesian consensus. The character of this progressive movement of trade unions, social groups and civil society was however limited to "defensive defiance". A number of questions are posed such as: What was the nature of the resistance to neoliberalism in BC in 1983, and to what extent did it succeed? Leftist analysts hotly debated these questions at the time, and a review in hindsight of their views is instructive. And to what degree have the neoliberal agenda and strategy and tactics changed in the ensuing years? Our review in this article suggests both a remarkable continuity and some fundamental changes. Analysis of these events therefore remains historically relevant to those concerned with pan-Canadian political trends.

Résumé

Cet article fait une analyse critique de l'expérience du mouvement de Solidarity en 1983 en Colombie Britannique, à une période qui a marqué la première révolution néolibérale complète au Canada. Ce moment a également signalé le début d'un
\end{abstract}

Ted Richmond is instructor in the Chang School at Ryerson University. He has worked in research and policy with universities, government, private foundations and community organizations. Ted has a Master's degree from OISE, University of Toronto, with a specialisation in statistics and evaluation. Among other publications in academic journals and community-based sources he is co-author/editor of the book Social Inclusion: Canadian Perspectives (with Anver Saloojee), Laidlaw Foundation and Fernwood Publishing, 2005. John Shields is Professor in the Department of Politics and Public Administration at Ryerson University. He is currently the Managing Editor of the Journal of International Migration and Integration published out of The Netherlands by Springer. Among his co-authored books are Dismantling a Nation: The Transition to Corporate Rule in Canada, 2nd edition (with Stephen McBride), Fernwood, 1997; and Shrinking the State: Globalization and Public Administration "Reform", Fernwood, 1998 (with Bryan Evans).

Ted Richmond est instructeur au Chang School à l'université de Ryerson. II a fait de la recherche et contribué à développer des politiques publiques avec des universités, des gouvernements, des fondations privées et des organisations de la société civile. Ted a un Masters d'OISE à l'université de Toronto, avec une spécialisation dans les statistiques et l'évaluation. Entre autres publications dans les revues universitaires et associatives, il est co-auteur et rédacteur du livre Social Inclusion: Canadian Perspectives (avec Anver Saloojee), Laidlaw Foundation et Fernwood Publishing, 2005. John Shields est Professeur dans le département de politique et d'administration publique à l'université de Ryerson. Il est le rédacteur gérant de la revue Journal of International Migration and Integration publiée dans le Pays-Bas par Springer. Parmi ses livres, il a co-écrit Dismantling a Nation: The Transition to Corporate Rule in Canada, deuxième édition (avec Stephen McBride), Fernwood, 1997; et Shrinking the State: Globalization and Public Administration "Reform", Fernwood, 1998 (avec Bryan Evans). 
RICHMOND and SHIELDS: Reflections on Resistance to Neoliberalism

mouvement important de résistance extra-parlementaire aux efforts néolibéraux de déconstruction des acquis sociaux et économiques qui ont été gagnés pendant la période du consensus keynésien. Le caractère de ce mouvement rassemblant des syndicats, certains groupes sociaux et des membres de la société civile était cependant limité à une 'défiance défensive'. Plusieurs questions sont posées, parmi lesquelles: Quelle est la nature de la résistance au néolibéralisme en Colombie Britannique en 1983 et à quel point a-t-elle réussi? Des analystes de gauche ont vivement débattu de ces questions à l'époque et une revue rétrospective de leurs débats est utile. Dans quelle mesure le programme et la stratégie/tactique néolibérale ont-ils changé dans les années qui ont suivi? Notre rétrospective dans cet article suggère à la fois une continuité remarquable et quelques changements fondamentaux. Une analyse de ces évènements reste historiquement pertinente pour ceux et celles qui s'intéressent aux développements politiques au Canada.

\section{Keywords}

Defensive defiance; neoliberalism; political strikes; social movement; Solidarity

Mots-clés

Défiance défensive; néolibéralisme; grèves politiques; mouvement sociaux ; Solidarity

This article looks back at the experience of the Solidarity movement in British Columbia (BC) in 1983, when that province was engaged in Canada's first extensive neoliberal transformation. The outcome of that struggle would be watched closely, and would help to shape the policy agendas of governments as well as the popular resistance across the country for decades to come. Our paper reviews the main events and the key contemporary comment of engaged activists and academics. It also provides some reflections on the lessons of this struggle for those who continue to oppose neoliberal globalization. Rather than reinterpreting the insights of those who provided critical analysis at the time of Solidarity, we have attempted to succinctly but accurately summarize their views, and to add our own analysis on their relevance today. Our paper seeks to re-visit Solidarity and the neoliberal moment that brought it into existence in order to better understand this formative event's significance in relation to the advance of neoliberalism in Canada, and the on-going progressive opposition to it.

The right wing agenda of the Social Credit (Socred) government in $\mathrm{BC}$ shook the socio-economic fabric of the province. A dissident political consciousness began to awaken; at the same time the popular mobilization alarmed other segments of the population and pushed them into the government's camp. By November 1983, BC was in a state of political crisis, 
and society had become polarized to a degree unknown since the Great Depression of the 1930s.

What was the nature of the resistance to neoliberalism in BC in 1983, and to what extent did it succeed? Analysts on the left hotly debated these questions at the time, and a review in hindsight of their views may be instructive. To what degree have the neoliberal agenda, strategy and tactics changed in the ensuing years? Our review in this paper suggests both a remarkable continuity and some fundamental changes.

Analysis of these events therefore remains historically relevant to those concerned with pan-Canadian political trends. More particularly, this analysis provides some perspective and possibly some insights for those who continue to resist the process of neoliberal globalization, which has continued for decades - often in new forms - following the Solidarity experience in BC.

\section{Setting the Scene: Neoliberalism Comes to BC}

The introduction in 1983 of a provincial budget along with a sweeping set of 26 legislative bills by the Socred Government of William Bennett was unprecedented in its scope and in its shifting of policy agendas and discourse to the political right. It represented a deliberate frontal assault on many of the foundations of the established broad Keynesian social and political consensus in the province and within Canada. Even for a right-ofcentre populist party, which the Socreds represented, in a province with a rather rich history of left-right political divisions (Resnick 2000), this was a bold and provocative move by a government intent on imposing, what until then, was a "hidden" neoliberal ideological policy agenda (Resnick 1986, 22).

Fresh from an election victory in 1983 over its social democratic NDP rivals, the Socred Government introduced its budget and legislative agenda. While the need for restraint was a Socred theme during the election, no hint of the extent and depth of change was discussed during the campaign, so the content of 1983 budget came as a surprise to the province (Block 1984, 8; and Kinsella 1985, 11-12).

The 1983 Budget measures were not about cutting government costs in the immediate term, as the recession of the early 1980s had generated budget deficits. Rather they were about establishing the framework and momentum for redrawing the public policy agenda away from social expenditures and other legitimation functions of the state toward areas that would help liberate market forces, and create a climate very favourable to capital accumulation and business investment. These 
included deregulation, lower corporate taxes and constraining the power of trade unions. The Fraser Institute's Michael Walker tellingly suggested that the budget was a beachhead designed to open up the ideological struggle to downsize government (Mcintosh 1983, C7).

The Government's claim that the budget deficit was structural rather than cyclical added weight to their position regarding the need for a major rethinking and reorientation of state spending (Redish and Schworm 1986), a position which would be usefully employed by subsequent neoliberal governments in Canada (Lewis 2003). Bennett argued that this "new economic reality" required government to "take a common sense" and "practical approach" to state spending and to manage state finances more like the family budget (Bennett 1983, 1188; BC Budget 1982, 2). This $\mathrm{BC}$ version of the common sense revolution included not just bringing in balanced budgets, but creating a more balanced society where the state's role was greatly reduced, and the private market enhanced and allowed to work its creative and productive powers.

Tactically the Socreds chose to implement their neoliberal agenda through what Allan Garr termed the "big-bang strategy". This strategy consisted of introducing the core elements of their program in one comprehensive package without forwarning. By failing to engage in a process of broad consultation on the policy changes and decisively attacking a broad range of interests at once, the government felt that the opposition would be caught off guard and be unable to organize an effective resistance (Garr 1985, 260).

Aside from the broader goals of the measures identified above, the Budget and the accompanying 26 Bills could be broken down into four distinct categories: 1) measures designed to strip collective bargaining rights from public sector workers and to shrink their numbers; 2) statutes which rolled back renter and human rights; 3 ) policies aimed at dismantling various other publically supported social and human services; and, 4) measures that centralized power in the hands of the cabinet so that they would be given a freer hand to make "necessary" policy decisions or handle dissent (Shields 1989, 256).

The totality of these measures fit well with generic neoliberal principles. Broadly, neoliberal aims have been centred on shrinking the state and restoring the market since "government failure" is seen as the chief cause of economic and social problems. This shift was particularly targeted against Keynesian regulatory and social policies, in favour of more neo-classical economic laissez-faire orientations. Moreover, neoliberalism seeks to redefine citizenship rights away from its more inclusive social and 
economic dimensions as encompassed in the Keynesian social contract to a narrower "lean" form of citizenship - a market based citizenship - stripped of collective socio-economic rights content (Burke, Mooers, and Shields $2000,12-13$ ). Additionally, neoliberalism is about shaping public policy alignment with the interests of global capitalism, and in this regard we are said to have no alternative but to adjust to the logical of neoliberal globalization because of structural economic pressures (Saad-Filho and Johnston, 2005). Finally, "special interests" empowered by the Keynesian welfare state (unions, public sector bureaucrats, the liberal media and intellectual elite, etc.) must be checked to control their excessive power and contain their demands on the state for special rights and benefits. This has created, according to neoliberals, demand overload resulting in state fiscal crisis and a more generalized problem of a "crisis of democracy", as state capacities became overwhelmed (McBride and Shields 1997, 28-29; Crozier et al. 1975, 6-12).

It is important to note that $\mathrm{BC}$ was a particularly receptive host to neoliberal ideals because it did have the sharpest left-right divisions in the country (Howlett and Brownsey 1988), and because the business community had organized in resistance to the threat of another NDP government, which had held power from 1972-75. They did this by not only actively supporting the Socreds, but also by financing the establishment the Vancouver-based Fraser Institute which since the 1970s had become an incubator of right wing thinking and a popularizer of its neoliberal ideas. The Fraser Institute's stated purpose was to work for the "redirection of public attention to the role of competitive markets in providing for the well-being of Canadians" (Ohashi and Roth 1980, inside front cover). The Fraser Institute was one of the few groups the government consulted concerning the 1983 Budget. The high praise given by the Institute for the government's measures in 1983 is indicative of both the neoliberal content of the Socred's agenda and the influence of the Institute over government policy thinking. The Institute's leading figure Michael Walker $(1983,8)$ called the budget in approving tones a "little revolution" (Mcintosh 1983, C7). As Walker noted, Premier Bennett had "turn[ed] on its head...the acceptable notion of what was politically possible and acceptable for governments to do." The political right in Canada, linked into a larger international network, had nurtured the development of think tanks as part of a longer-term strategy to win the battle of ideas (Brownlee 2005) that was necessary to unseat the hegemony of the Keynesian policy paradigm. 
Since Canadian governance is characterized by federalism where regional governments possess considerable power, what happens in the provinces is significant for policy learning in other Canadian jurisdictions. In earlier periods progressive social policy had spread out from provinces like Saskatchewan under social democratic government as in the case of medicare. In the 1980s BC would become a learning laboratory for neoliberal policy innovation.

\section{A Brief History of the Political Mobilization}

The sweeping neoliberal agenda represented by the 1983 budget and legislative measures generated strong reaction. In particular, it led to the rapid creation of an extra-parliamentary opposition, which marched under the banner of Solidarity. BC's right wing neoliberal revolution generated in true Polanyian fashion a "double movement" (Polanyi 2001) by a progressive opposition, a political protest movement unlike any other in the history of the province.

The Socred government's 1983 budget "revolution" generated a reaction of initial disbelief, tension and a measure of disorganization as the NDP, the media, trade unions and community groups struggled to grasp what it all meant and to absorb the enormity of the changes (Kieran 1983, A2). It was the Socreds' intention to radically alter the balance between the public and private sectors, and dismantle rights, which quite naturally aroused strong reactions.

The NDP, as Her Majesty's Loyal Opposition, was the first to oppose the government. It was a vocal critic of the restraint program, working actively to resist its implementation. However, its struggle against the legislation was waged strictly as a parliamentary battle. The NDP utilized every avenue and tactic in its legislative arsenal in an attempt to block, or at least delay for as long as possible, the passage of the most offensive statutes.

The Socreds were, however, able to blunt the effectiveness of this opposition through the use (or misuse) of parliamentary procedures such as marathon sessions, closure and eventually the physical expulsion of the leader of the opposition. In a province with a history of rough and tumble politics both inside and outside the Legislature, the July 1983 legislative session presented a special challenge to democratic parliamentary practice. In order to push its 26 bills through the legislature, the Socred government adopted a practice of legislation by exhaustion without the opportunity for substantive debate. Closure, not used in BC since 1957, was invoked no less than 20 times (Wilson 1984, 123, 126). The 
government's unwilling to moderate in the face of intense parliamentary resistance, however, showed the limitations of representative democratic institutions, revealing legislatures to be, in this instance, simply "talk shops" (Yandle 1984, 5).

Outside of the Legislature the reaction to the Socreds' intransigence was a degree of protest and popular mobilization that illustrated the gulf that had come to separate the population from the government and its socalled "restraint" program. The mood of frustration and anger displayed by public sector workers such as the disgruntled BC teachers (Ballard, 1983) over the government's refusal to moderate its sweeping "restraint" program, even in the face of massive disapproval, expressed how deeply the 1983 Budget touched and activated even normally non-political British Columbians. Government supporters, on the other hand, construed Solidarity as not only a disruptive force but a potential threat to democratic government itself (Mulgrew 1983, 4).

This non-institutionalized form of opposition took the form of "the broadest social movement in the province's history" (Diamond 1984, 268). Historically the BC union movement has a tradition of militancy and political activism, often providing a core of mobilization around which community groups could coalesce (Carroll 1984, 110). But the Solidarity movement grew rapidly into something more than an adjunct to labour mobilization, setting new directions for progressive struggle in the province.

The Solidarity movement developed as separate but coordinated networks of both labour and community organizations. One wing of the movement was Operation Solidarity, the trade union element. It was an organization founded by the province's central labour organization, the BC Federation of Labour (BC Fed). Operation Solidarity, however, looked beyond its own Federation membership and sought to speak for nearly every organized worker in the province.

The other wing of the protest movement was rooted in community organizations and broader community concern. The Solidarity Coalition invited under its umbrella any group or organization in $\mathrm{BC}$ that opposed the Socreds' budget and legislative package. It was comprised of a broad spectrum of interests ranging from professionals to the unemployed, consumers to small business, feminists to ethnic minorities, environmentalists as well as the disabled, in short, the so-called community group elements within civil society (Solidarity Coalition Bulletin 1983, 2-3). The political range within this component of Solidarity was consequently also very broad, ranging from real progressive 
conservatives to communist and anarchistic elements, united by what they opposed rather than a particular alternative vision.

On 15 July BC Fed President Art Kube organized a conference inviting both Federation-affiliated and non-affiliated unions. This was key to building an alliance with the more than 75,000 public sector unions representing teachers, hospital workers and nurses. The conference represented the birth of Operation Solidarity, the labour wing of the Solidarity movement (Pacific Tribune 1983, 1).

The first popular organization to arise in reaction to the government's moves was the Lower Mainland Budget Coalition (LMBC). It was the creation of the Vancouver and District Labour Council's Unemployment Action Centre and representatives from over fifty community groups and unions in the city (Carroll 1984, 96). Labour leaders and members of the Communist party were instrumental in initial organizing, but the impetus came from hundreds of community members angered by the Socred agenda.

The LMBC adopted the operating principle that "an injury to one is an injury to all", and made itself open to all organizations committed to defeating the Socred budget and legislative program and fighting for the defence and enhancement of economic, democratic and human rights (Lower Mainland Budget Coalition n.d.). The Budget Coalition organized a rally on short notice for 23 July, and drew an estimated 25,000 supporters, surpassing the expectations of even the most optimistic (Solidarity Times 1983, 5).

By the end of July the two structures joined together politically under the Solidarity banner. Operation Solidarity was the main trade union wing of the movement, under the direction of the BC Fed. Every major BC community also had a local Solidarity Coalition, although the largest by far was the Lower Mainland Solidarity Coalition (originally the Lower Mainland Budget Coalition). Some unions were active in the locally based Solidarity coalitions, particularly the Canadian unions not affiliated with the BC Fed.

The remade Solidarity movement devised a three-phase campaign of action designed to pressure the government into retreating on the legislation. Phase one would encompass mass rallies. Phase two would diversify the protest and pressure tactics. The second phase included placing legislative pressure on the government by supporting NDP filibustering, having a continuous Solidarity presence at the Legislature, filling the gallery during debates, and contacting individual Socred MLAs. Also organized as part of phase two was a "Speak Out" campaign with a 
petition and buttons to wear to work. As well, attention would be focused on particular issues like human rights, or education, during particular weeks. The final phase of action would involve public sector bargaining, and industrial action, although the direction this would take was not immediately clear (Kuehn 1983, 1).

Within Operation Solidarity, there was considerable discussion about the plans for gradually escalating strikes, and the related issues of legal and illegal strikes, and direct political action. At the founding of Operation Solidarity, the BC Fed leader Art Kube had rejected the notion of a full-fledged general strike. Union leaders and activists were also preoccupied with maintaining support from the media and the general public.

Meanwhile the Socred government responded with its own tactics to counter the plan of action from Operation Solidarity - suspending the legislature for a "cooling off" period, postponing some scheduled layoffs, and making deals with particular unions. They also escalated their rhetorical denunciation of the Solidarity movement, and threats of punitive action against the unions and their leaders. Nevertheless, union opposition to the government continued to grow, particularly in terms of opposition to Bill 3, which aimed to slash the size of the civil service. Despite attempts at dividing the teachers' union and their strike plans, between 80 and 90 percent of the members joined a strike called by their leaders (McLintock 1983, 27).

In the late summer and fall of 1983 the growing numbers at Solidarity-organized demonstrations showed the gathering public support for the movement. A major rally at Vancouver's Empire Stadium on 10 August drew more than 40,000; effectively this was a short public sector general strike as workers left their jobs to join in. The demonstration on 15 October turned into the largest anti-government mobilization in BC history, with between 50,000 and 60,000 people marching past the Socred Party's annual convention in downtown Vancouver (Sarti 1983, A16). At the rallying point Solidarity presented "A Declaration of Rights of the People of British Columbia", a charter that endorsed as fundamental the sanctity of the very rights the government was attempting to dismantle. BC Solidarity had developed into a major social movement.

In November of 1983 the titanic struggle between Solidarity and the government climaxed in an escalating public sector strike. A settlement was reached, the so-called "Kelowna Accord", only hours before an ultimate and seemingly irreversible showdown was to occur. Except for the resolution of a formal contract dispute with the BC Government 
Employees Union (BCGEU), the Kelowna Accord was a verbal deal between representatives of the Socred government and the union leaders of Operation Solidarity. Interpretation of the deal was therefore subject to possible misunderstanding or further negotiation.

In essence the Kelowna Accord provided for the following according to Operation Solidarity:

- The BCGEU settlement would exempt the union from Bill 3, and this contract provision would serve as a model for the exemption of other unions from Bill 3. This Bill essentially gave government a free hand to lay off workers without regard to negotiated contract provisions such as seniority;

- Bill 2, the Public Service Labour Relations Amendment Act, would be allowed to die on the order paper. This Bill would have stripped the right of the union to negotiate, anything other than wages, terms and conditions of work with their employer;

- No reprisals would be directed against any of the strikers or their unions;

- There would be ministerial consultation with respect to rent control legislation;

- There would be advisory commissions established for the purpose of public consultation on Human Rights and Labour Code legislative changes;

- Consultation mechanisms would be established for individuals and groups for the purpose of proposing alternative budget priority suggestions; and

- Money saved on teachers' salaries during the strike would be returned to the education budget, purportedly to avert the necessity of teacher layoffs (Larkin 1984, 6).

The last point of the agreement caused conflict over the next few months, with the government demanding that teachers make up the three work days lost during the strike before any savings would be returned to the school system. Operation Solidarity threatened to reactivate the strike but practically this was not possible, and the government interpretation prevailed. However, the Kelowna Accord provided important victories for Operation Solidarity and its supporters in relation to two of the most offensive pieces of the proposed labour legislation. Public sector unions were allowed to preserve the principle of seniority rights through 
exemptions to Bill 3, and the withdrawal of Bill 2 allowed the BCGEU to maintain bargaining rights over multiple issues - critical to the preservation of "free" collective bargaining.

None of the labour leaders saw the Kelowna Accord as an unmitigated victory; the most optimistic spoke in terms of limited and symbolic gains - the defeat of key pieces of legislation, and the building of solidarity and struggle. The labour leaders also believed that they had made some progress on the social issues of most concern to their partners in the Solidarity Coalition. There were intense debates within organized labour over the use of "political strikes", and a future orientation towards business or social unionism. But these remained largely internal to the trade union movement.

The dissatisfaction of the Solidarity Coalition with the Kelowna Accord, however, was more public. Many of its spokespersons publicly chastised Operation Solidarity for its failure to consult with its coalition partners, and for labour's failure to stay on the picket lines until resolution of the concerns of the community groups. Many within the Solidarity Coalition viewed these omissions as a betrayal by the labour leadership (Glavin 1983, A1). The situation was aggravated by the unfortunate fact that the main Operation Solidarity leader Art Kube, who had facilitated much of the on-going communications between organized labour and community representatives, fell ill during the negotiations of the Kelowna Accord and withdrew from the negotiations. Nevertheless, it was clear that the leaders of Operation Solidarity had given only cosmetic treatment to the main concerns of their community partners, such as human and tenant rights. That the union leaders saw these as "political" issues to be resolved through the ballot box revealed the depth of differences between the two wings of the movement.

After the Kelowna accord, Solidarity passed from a mass extraparliamentary opposition movement to a much smaller and more institutionalized government watchdog organization. In spite of a sense of betrayal by their union partners, the Solidarity Coalition vowed to continue the battle around social issues and human rights.

Solidarity remained an active critic of the Socred government, becoming a continuing source of media attention as a counter to government policy on labour and social issues. The experience also developed a new level of collaboration and unity in the $\mathrm{BC}$ trade union movement, particularly between private and public sector unions, a unity that would become very important in the unions struggle in 1987 against an attempt to overhaul the BC Labour Code along neoliberal lines. This 
unity was maintained through active communications and collaboration in the years immediately following 1983 . No doubt influenced by the tensions between the community sector and organized labour as a result of the Solidarity experience the battle against the sweeping 1987 BC labour code changes took the form of a union directed and focused boycott which to a large degree effectively negated the worst aspects of the legislative changes (Shields 1991).

\section{Analysis of the Events}

Interpretations by Left-Wing Analysts

The dramatic experience of the Solidarity movement and its confrontation with the BC Socred government quite naturally gave rise to considerable commentary by left-wing analysts. The most extensive account came from historian Bryan Palmer, who saw a movement with exhilarating potential led to a crushing defeat by its leaders. Palmer's analysis focused on the role of the labour bureaucracy and social democratic reformism in the downfall of Solidarity. He highlighted in particular:

- Insufficient or even false information provided by the movement's leaders to its supporters, and their role in demobilizing or limiting mass action;

- The suspicion and fear of the NDP in relation to any mass movement outside the parliamentary arena; and,

- The resistance of the labour leadership in $\mathrm{BC}$ to engagement in grassroots militant and revolutionary working class struggle.

For Palmer, the Solidarity movement could have won great victories if the leaders had not sabotaged its evolution towards a general strike (Palmer 1987, 88-103).

Maurice Rush of the Communist Party of Canada provided a more favourable assessment of the Solidarity experience, emphasizing the gains that were achieved, the historic significance of the trade union leaders' engagement in extra-parliamentary struggle (led by the public sector unions), and the enduring legacy of united popular struggle $(1984,10)$. Philip Resnick's observations challenged those like Palmer who saw potential victory through a general strike. Resnick questioned the prospects of a prolonged public sector strike without substantial private sector union engagement, and noted the risk of driving public opinion into the Socred's camp. For Resnick the victory of Solidarity was in the struggle 
itself. The movement showed that a neo-conservative/neoliberal agenda could not be implemented with impunity in $\mathrm{BC}$, or presumably in the rest of Canada $(1986,34)$. William Carroll viewed the Solidarity experience as a limited and defensive reaction to a neo-conservative/neoliberal revolution in BC. For Carroll the conservatism and bureaucratic habits of the union leaders were too entrenched to permit them to lead and win the militant struggle that was required. However, the grassroots organizations in the Solidarity Coalition, representing the community sector of the movement, had more potential to develop a counter-hegemonic force opposing the neoliberal agenda. The failure to achieve this goal was due to a number of key weaknesses in the left opposition:

- The organizational divisions and communication gaps between the two wings of the movement;

- A lack of priorities in the movement's opposition to the government legislation, leading to an inability to impose a reasonable compromise as dictated by political necessity;

- The split between "trade union" and "social/political" issues within the movement; and,

- Solidarity's failure to articulate and discuss a social alternative to neoliberalism.

Carroll concluded that these weaknesses resulted in the $\mathrm{BC}$ left reverting to old-style Keynesian solutions after the Solidarity experience, while neoliberalism became the dominant ideological force (Carroll 1984, 104; Carroll 1987).

\section{Review of the Left Analysis}

Given the nature of the economic and political forces within which the Solidarity movement developed, what should we think in retrospect of the analysis provided by contemporary left observers? Was Solidarity a failure or success? What forces strengthened or weakened the movement? What role did the labour leadership, and the fragile alliance between unions and community groups play? And what did the Socred government, and other neoliberal forces across Canada, learn from the experience?

Palmer argued that both labour and community groups were betrayed by reformist union bureaucrats who would not or could not lead the class struggle. While there is no doubt that the $\mathrm{BC}$ trade union leaders were reformist and social democratic, it is not so clear that the majority of rank-and-file union leaders were more class conscious or potentially 
revolutionary. And what evidence do we have that a constant escalation of tactics and political demands - culminating in a general strike for the complete abolition of all the Socred legislation - would have produced victory for the popular movement rather than a political crisis ultimately consolidating the power of the Socred government?

Both Rush and Resnick provided relevant responses to Palmer's perspective. Rush observes that the BC trade union leaders did in fact engage in a degree of extra-parliamentary struggle that while ultimately perhaps too constrained, went far beyond the limits of previous struggles. And Resnick questioned the possibility of achieving victory for all of Solidarity's demands through a general strike, given the ambiguity of public opinion towards general strikes in liberal democracies. Both Rush and Resnick suggested - correctly we believe - that the Solidarity experience could not be accurately labelled as either a victory or a failure. The Solidarity movement at a minimum had demonstrated that popular forces in $\mathrm{BC}$ were willing to "unite and fight" against the radical right-wing agenda.

Of all the authors who provided critical reviews of the Solidarity experience, Carroll provided the analysis which best stands the test of time. He correctly identified the limited and defensive character of the opposition to the imposition of the neoliberal agenda in $\mathrm{BC}$. He also recognized the importance of the numerous displays of militancy displayed in the struggle. Finally, and most importantly, Carroll identified the opposition's failure to develop its own program as a counter hegemonic force to the neoliberal policy agenda. In this context it is worth recalling Piven and Cloward's (1979, xiii) observation that: "What was won must be judged by what was possible."

In retrospect it seems evident that Palmer did raise an important point regarding the failure of the leadership in the union movement, as demonstrated by its inability to move beyond narrow trade union consciousness. Such movement would be required to build a counter hegemonic paradigm, beyond the obvious limits of Keynesianism, to neoliberalism. However, this was a more generalized problem among progressive forces that limited popular mobilization in resistance to neoliberalism to a decidedly defensive posture, and also made it difficult to compete effectively with neoliberal forces in the larger term battle of ideas.

What the Solidarity experience did reveal was that a new era of politics had arisen for British Columbia, and ultimately of course across Canada and globally. It was characterized by the appearance of mass extraparliamentary resistance to the emerging and fundamental shift in state 
Socialist Studies / Études socialistes 7(1/2) Spring/Fall 2011: 216-237

policies, and by the scramble of popular forces to develop alliances and strategies capable or resisting the erosion of the Keynesian welfare state.

\section{The Significance of the Solidarity Experience}

\section{Plus Ça Change...}

Looking back on the Solidarity experience, it is striking to see how little the core aims of the neoliberal agenda have changed. The erosion of the welfare state and related workers' and human rights have remained central to the agenda of both provincial and federal governments for the nearly three decades since the trade unions and community groups of $\mathrm{BC}$ challenged the ruling Socred government. Many of the methods of imposing these changes have remained constant as well, from the disruption of basic parliamentary procedures, to the harsh criticism of the opposition as enemies of democracy and economic progress.

Much has changed in this time of course, both in Canada and in the world. Perhaps most striking is the pace of globalization of the economy and the labour market (McBride 2005). Along with restrictions and rollbacks of the rights of unionized and nonunionized workers (Panitch and Swartz 2003), we are witness to a constant increase in economic polarization (Olsen 2011; Federation of Canadian Municipalities 2008) and the pervasive nature of precarious work (Burke and Shields 2000, Vosko 2000). While immigrants and racialized groups bear the brunt of the most extreme forms of temporary and precarious labour (Shields 2004; Sassen 1999), the new rules of work now extend even to young professionals who routinely do unpaid with the hope of eventually winning the right to paid employment. Side-by-side with the international triumph of market economics are the globalization of popular struggles and the internationalization of political issues (Held and McGrew 2007; Panitch and Leys 2002). The opposition to the two Iraq wars and military intervention in Afghanistan, as well as the broad support for militant environmentalism, are two examples that come to mind.

At the same time these past decades have been defined by a relentless ideological assault on the social citizenship rights that defined the post-World War II social contract and the political consensus represented by the welfare state (Coutu 2006). Citizens are now construed as little more than consumers, not only in the economic marketplace and labour market, but also as members of civil society (Sears 2003). Electoral campaigns are based on an appeal to the votes of these "consumers" for economic bargains through reduced taxes, with little serious public 
discussion of the consequences in terms of elimination of public goods. Opposition to the neoliberal agenda has largely been transformed from "inadvisable" to "impossible", and alternative agendas removed from consideration. The development of a political agenda - whether broad or narrow - requires as a precondition that it be framed in terms of neoliberal values of reduced government, deficit reduction, and the predominance of market forces. There is a chilling degree of truth in the assertion of George Monbiot (2007) that "We are all neoliberals now."

Accompanying the ideological assault of neoliberalism - in Canada at least - has been a shift in strategy and tactics for achieving the desired economic and political transformation. With the notable exception of the Mike Harris "Common Sense Revolution" in Ontario in the late 1990s, and the more targeted but aggressive attacks on BC labour in 1987 and 2000 (Camfield 2006) the implementation of the neoliberal agenda has been characterized less by frontal assault as per the BC Solidarity era, as typified by the tactics of "first wave neoliberalism" (Steger and Roy 2010), and more by a kind of relentless incrementalism. In the process the welfare state has come to be gradually "hollowed out" (Jessop 2002), although the façade remains.

One of the lessons of the BC Solidarity experience for the right-wing forces, and one that appears to have had great impact, was that a frontal assault approach, while not totally abandoned, runs a considerable risk of radicalizing the popular opposition. From proroguing our federal Parliament at the convenience of a minority government, to gradual privatization of the health care system and corporatization of the universities, the march of neoliberalism has been steady and the accumulation of victories impressive. Particularly striking in recent years has been the promotion and growth of the military and police apparatus within government. The massive investments in Canada's armed forces and the criminalization of dissent during the G20 protests in Toronto in 2010 provide dramatic proof that the bloated and unproductive portion of government that the neoliberals want to eliminate does not include the apparatus of "law and order" and repression (Paris 2011, 22-30).

The Solidarity experience in BC in 1983 was characterized by a frontal assault on social services, union rights and human liberties. The portrayal of this assault as a form of progress towards a new era of economic progress and political liberty was an important aspect of the conflict, and one that would grow in significance throughout Canada for decades to come. Significantly, this frontal assault developed a mass and militant extra-parliamentary resistance, uniting a variety of both working 
class and middle class forces against the government, and polarizing opposition to the neoliberal agenda in a manner that would not soon be forgotten. However, sustaining the unity, let alone the mobilization, of a popular opposition to neoliberalism has been made particularly challenging because of the inability of popular forces to develop their own counter hegemonic agenda that is able to move beyond the extremely limited vision of the now dated Keynesian paradigm.

\section{Issues to Consider}

The issues posed by the dominance of neoliberalism are vast. Certainly it is far beyond our capacity in this or any single article to categorize them, much less to provide substantive analysis. In the spirit of reflection and debate, however, let us suggest three topics that strike us as particularly worthy of consideration in relation to the BC Solidarity experience.

First, what is the significance of the global nature of economic restructuring and resistance? What does the increasingly globalized nature of the struggle against neoliberalism mean for developing an alternative political vision? What are the implications of specific trends such as global ecopolitics, and international anti-war mobilization? What is the effect of ideological trends such as the implicit but essentially anarchist nature of global solidarity movements? And how can the politically and technologically "wired" nature of global protest be used to shape and strengthen concrete domestic political alternatives?

More locally, what is the role of community organizations in the continuing development of an extra-parliamentary opposition to the imposition of the neoliberal agenda? In Ontario in particular we appear to have experienced a more diffused but nevertheless persistent opposition to neoliberalism from various organizations and alliances rooted in the community services sector. To what extent is this form of opposition rooted in a different political economy and political infrastructure, particularly the triumph of new public management and the divesture of state services to contracted community organizations? And to what degree can this moderate yet persistent opposition continue to contribute to resistance to the neoliberal agenda?

Looking more globally again, what can we say at this point in the twenty-first century about the link between socialism and democracy? Undoubtedly work must continue to analyze and expose the links between capitalist globalization and the degradation of workers' rights, general human rights and the environment. At the same time we must admit that neoliberalism has been largely successful in establishing a significant 
popular consensus associating individual liberty with a capitalist economy. Perhaps it is time to revisit the libertarian ideals of the Marxists and anarchists of the early twentieth century, and the international New Left of the 1960s and 1970s, in order to re-establish the credibility of the socialist claim to freedom.

\section{Conclusion}

The political events in British Columbia formed the cutting edge of the attack by the new right in Canada, representing a local expression of a new politics already evinced in Thatcherism and Reagonomics. That scope of the challenge posed to the post-war social contract was evident in the 1983 Budget of the governing Social Credit Party. The immediate result was a mobilization and politicization of popular forces in defense of the welfare state. When the political strike action by Solidarity achieved a measure denied to the legislative efforts of the New Democratic Party, an end was signaled to the politics of consensus and the channeling of popular dissent into parliamentary processes. Ultimately however Solidarity offered no broad and long-term alternative vision to that of the neoliberals, and the victories of the movement were only partial and time limited. The Solidarity movement was characterized essentially by a broad-based and militant "defensive defiance" which only limited, or postponed, the achievement of neoliberal economic and political goals.

With some notable exceptions like the Mike Harris years in the late 1990s in Ontario (Camfield 2000), the imposition of the neoliberal agenda in Canada has been characterized less by the frontal assault of the BC Solidarity period, and more by a relentless incrementalism in policy and program. At the same time the alleged necessity of these incremental changes finds ever-new and more pervasive justification in an unrelenting ideological assault on the fundamental notions of social and citizenship rights beyond the limits of "free" market relations.

This situation could change rapidly of course, in any particular province, or for Canada as a whole. The neoliberal forces might well be sufficiently heartened by examples like Cameron's agenda (Seymour 2010; Hutton and Penny 2010) in the United Kingdom to return to a strategy of whole-scale frontal assault on the remnants of the welfare state and the related rights of workers and citizens. This has become a particular greater possibility in the context of the return to "public sector austerity" agenda resulting from the global financial crisis of 2007-2008 (Albo and Evans 2010). But for now at least, in Canada, it would appear that the leaders of the neoliberal crusade are content to patiently implement their agenda in 
bits and pieces, while engineering the public discourse to eliminate the very possibility of alternatives. The risk of large-scale class and social conflict that comes with the alternative agenda of frontal assault may be judged as simply too great. The experience of the Solidarity movement in $\mathrm{BC}$ and current popular mobilizations against austerity may well be convincing pieces of evidence to justify this conclusion.

Under these conditions, it will remain exceedingly difficult for progressive forms to move beyond a series of defensive struggles in reaction to the long march of neoliberal reform. As in BC, moving beyond a defensive reaction requires not only leaders with credible strategies and practical tactics, but also the energy and cohesion provided by an alternative vision. Developing such a vision of course presents enormous challenges, especially if there is more concern with popular credibility than political correctness. But these challenges must be addressed if any serious movement to block and ultimately defeat the global imposition of neoliberalism is to occur.

\section{References}

Albo, Greg and Bryan Evans. 2010. "From Rescue Strategies to Exit Strategies: The Struggle over Public Sector Austerity." In The Crisis This Time: Socialist Register 2011, ed. Leo Pantich, Greg Albo, and Vivek Chibber, 283-308. London: Merlin Press.

Ballard, Larry. 1983. Telepost, President, Windermere District Teachers' Association. 3 October 1983. In Larry Kuehn Paper, Box 4, File 9.

Bennett, William. B.C. 1983. Hansard 3, no. 12, 01 September 1983.

Block, Michael. 1984. "Election campaign may not be time to sell tough policy," The Financial Post, 19 May 1984, 8.

British Columbia, Government of. 1982. Budget. Victoria, BC: Queen's Printer, 1982.

Brownlee, Jamie. 2005. Ruling Canada: Corporate Cohesion and Democracy. Halifax, NS: Fernwood.

Burke, Mike, Colin Mooers, and John Shields (eds.). 2000. Restructuring and Resistance: Canadian Public Policy in an Age of Global Capitalism. Halifax, NS: Fernwood.

Burke, Mike and John Shields. 2000. "Tracking Inequality in the New Canadian Labour Market." In Restructuring and Resistance: Canadian Public Policy in an Age of Global Capitalism, ed. Mike Burke, Colin Mooers, and John Shields, 98-123. Halifax, NS: Fernwood.

Burke, Mike, Colin Mooers, and John Shields. 2000. "Introduction: Critical Perspectives on Canadian Public Policy." In Restructuring and Resistance: Canadian Public Policy in an Age of Global Capitalism, ed. Mike Burke, Colin Mooers, and John Shields, 11-23. Halifax, NS: Fernwood. 
RICHMOND and SHIELDS: Reflections on Resistance to Neoliberalism

Camfield, David. 2006. "Neoliberalism and Working Class Resistance in British Columbia: The Hospital Employees' Union Struggle, 2002-2004." Labour/Le Travail 57: 9-41.

Camfield, David. 2000. “Assessing Resistance In Harris's Ontario, 1995-1999." In Restructuring and Resistance: Canadian Public Policy in an Age of Global Capitalism, ed. Mike Burke, Colin Mooers, and John Shields, 306-317. Halifax, NS: Fernwood.

Carroll, William K. 1987. “Hegemony and Crisis in B.C.: 1983-1987.” Sociology 990 Seminar, University of Saskatchewan, October 8, 1987.

Carroll, William K. 1984. "The Solidarity Coalition." In The New Reality: The Politics of Restraint in British Columbia, ed. Warren Magnusson and others, 94-113. Vancouver: New Star Books.

Coutu, Michel. 2006. "The Crisis of the Welfare State and the Demise of Social Citizenship? A Sociological Perspective." In Law and Citizenship, ed. Law Commission of Canada, 119-143. Vancouver: UBC Press.

Crozier, Michael, Samuel P. Huntington, and Joji Watanuki. 1975. The Crisis of Democracy: The Report on the Governability of Democracies to the Trilateral Commission. New York: New York University Press.

Diamond, Sara. 1984. "Where the Fraser River Flows: The Birth of Solidarity in B.C." Fuse (Spring 1984): 266-268.

Federation of Canadian Municipalities (FCM). 2008. Falling Behind: Our Growing Income Gap. Ottawa: FCM,.

Glavin, Terry. 1983. “Kube booed at meeting,” The Vancouver Sun, 15 November 1983, A1.

Garr, Allen. 1985. Tough Guy: Bill Bennett and the Taking of British Columbia. Toronto: Key Porter.

Held, David and Anthony McGrew. 2007. Globalization/Anti-Globalization: Beyond the Great Divide. Cambridge: Polity.

Howlett, Michael and Keith Brownsey. 1988. "The Old Reality and the New Reality: Party Politics and Public Policy in British Columbia 1941-1987." Studies in Political Economy: A Socialist Review 25: 141-176.

Hutton, Robert and Thomas Penny. 2010. "Cameron Aims to Outdo Thatcher Tackling Welfare State." Bloomberg Businessweek, 18 October 2010, http://www.businessweek.com/news/2010-10-18/cameron-aims-to-outdothatcher-tackling-welfare-state.html.

Kieran, Brian. 1983. "Deluge of legislation creates bedlam in house," The Vancouver Sun, 8 July 1983, A2.

Kinsella, Patrick. 1985. “The Kinsella Tapes.” New Directions 1, no. 1: 8-14.

Kuehn, Larry. 1983. "Report on Operation Solidarity 'Think Thank'." August 14, 1983. In Larry Kuehn Papers, Box 5, File 9.

Jessop, Bob. 2002. The Future of the Capitalist State. Cambridge: Polity.

Larkin, Jackie. 1984. “The Settlement.” Canadian Dimension 18, no. 1: 6. 
Lewis, Timothy. 2003. In the Long Run We're All Dead: The Canadian Turn to Fiscal Restraint. Vancouver: UBC Press.

Lower Mainland Budget Coalition. n.d. "On the Creation of the Lower Mainland Budget Coalition." flier. In Larry Kuehn Ppapers, Box 4, File 6.

Magnusson, Warren et al (eds.). 1984. The New Reality: The Politics of Restraint in British Columbia. Vancouver: New Star Books.

McBride, Stephen. 2005. Paradigm Shift: Globalization and the Canadian State, 2nd edition. Halifax, NS: Fernwood.

McBride, Stephen and John Shields. 1997. Dismantling a Nation: The Transition to Corporate Rule in Canada. Halifax, NS: Fernwood.

Mcintosh, Gord. 1983. "'Little revolution' augurs well for future, says right-wing guru," The Vancouver Sun, 31 December 1983, C7.

McLintock, Barbara. 1983. "Strike pressure rising," The Vancouver Province, 6 November 1983, http://www.monbiot.com/2007/08/28/how-did-we-get-into-this-mess

Monbiot, George. 2007. "How Did We Get into this Mess?" The Guardian, 28 August 2007, http://www.monbiot.com/2007/08/28/how-did-we-get-into-this-mess

Mulgrew, Ian. 1983. "B.C. conflict turns bitter as labor unrest spreads," The Globe and Mail, 9 November 1983, 4.

Ohashi, T.M. and T.P. Roth. 1980. Privatization Theory and Practice. Vancouver: Fraser Institute.

Olsen, Gregg M. 2011. Power and Inequality: A Comparative Introduction. Toronto: Oxford University Press.

Pacific Tribune. 1983.“'We'll fight gov't' declares B.C. Fed," Pacific Tribune, 15 July 1983, 1.

Palmer, Bryan. 1987. Solidarity: The Rise and Fall of An Opposition in British Columbia. Vancouver: New Star Books.

Panitch, Leo and Colin Leys (eds.). 2002. Socialist Register 2002: A World of Contradictions. London: Merlin Press.

Panitch, Leo and Donald Swartz. 2003. From Consent to Coercion: The Assault on Trade Union Freedoms, 3rd edition. Aurora, ON: Garamond.

Paris, Erna. 2011. “The New Solitudes.” The Walrus (March 2011): 22-30.

Piven, Frances Fox and Richard A. Cloward. 1979. Poor People's Movements: Why They Succeed, How They Fail. New York: Vintage Books.

Polanyi, Karl. 2001. The Great Transformation: The Political and Economic Origins of Our Time. Boston: Beacon Press, 2001.

Redish, Angela and William Schworm. 1986. "Cyclical and Structural Elements in the Current Recession." In Restraining the Economy: Social Credit Economic Policies for B.C. in the Eighties, ed. Robert C. Allen and Gideon Rosenbluth, 69-89. Vancouver: New Star Books. 
RICHMOND and SHIELDS: Reflections on Resistance to Neoliberalism

Resnick, Philip. 1986. "Neo-Conservatism on the Periphery: The Lessons from B.C." Biennial Conference of the Association of Canadian Studies in Australia and New Zealand, Brisbane, 13-16 May 1986.

Resnick, Philip. 2000. Politics of Resentment: British Columbia, Regionalism and Canadian Unity. Vancouver: UBC Press.

Rush, Maurice. 1984. Solidarity: Lessons of the B.C. Fightback. Communist Party of Canada Pamphlet.

Saad-Filho, Alfredo and Deborah Johnston (eds.). 2005. Neoliberalism: A Critical Reader. London: Pluto Press.

Sarti, Bob. 1983. "Solidarity sets deadline," The Vancouver Sun, 17 October 1983, A16.

Sassen, Saskia. 1999. Globalization and Its Discontents. New York: The New Press, 1999.

Sears, Alan. 2003. Retooling the Mind Factory: Education in a Lean State. Aurora, ON: Garamond.

Seymour, Richard. 2010. The Meaning of David Cameron. Hants, UK: O Books.

Shields, John. 1989. British Columbia's New Reality: The Politics of Neo-conservatism and Defensive Defiance. PhD Thesis, University of British Columbia.

Shields, John. 1991. "Building a New Hegemony in British Columbia: Can NeoConservative Industrial Relations Succeed?" In Regulating Labour: The State, NeoConservatism and Industrial Relations, ed. Larry Haiven, Stephen McBride, and John Shields, 45-78. Toronto: Garamond Press.

Shields, John. 2004. "No Safe Haven: Work, Welfare, and the Growth of Immigrant Exclusion". In Immigrants, Welfare Reform, and the Poverty of Policy, ed. Philip Kretsedemas and Ana Aparicio, 35-60. Westport, Connecticut: Praeger.

Solidarity Coalition Bulletin. 15 September 1983.

Solidarity Times. 1983. "Solidarity: A history of its birth." Solidarity Times 1, no. 1: 5.

Steger, Manfred B. and Ravi K. Roy. 2010. Neoliberalism: A Very Short Introduction. Oxford: Oxford University Press.

Vosko, Leah F. 2000. Temporary Work: The Gendered Rise of a Precarious Employment Relationship. Toronto: University of Toronto Press.

Walker, Michael. 1983. "Political verities are being turned on head," The Financial Post, 2 July 1983, 8.

Wilson, Jeremy. 1984. “The Legislature Under Siege." In The New Reality: The Politics of Restraint in British Columbia, ed. Warren Magnusson et al, 114-130. Vancouver: New Star Books.

Yandle, Sharon. 1984. "The NDP in BC: Observing Their Friends on the Move." Canadian Dimension 15, no. 1: 15-17. 